\title{
Radiata pine response to tillage, fertilization, and weed control in Chile
}

\author{
Respuesta a la preparación de suelos, control de malezas y fertilización \\ en plantaciones de Pinus radiata en Chile
}

\author{
TIMOTHY J. ALBAUGH ${ }^{1}$, RAFAEL RUBILAR ${ }^{2}$, JOSÉ ALVAREZ ${ }^{3}$, H. LEE ALLEN ${ }^{2}$ \\ ${ }^{1}$ Box 8008, NCSU, Raleigh, NC 27695-8008, Voice: 919-515-3500 \\ Fax: 919-515-6193, email: tim_albaugh@ncsu.edu \\ ${ }^{2}$ Box 8008, Department of Forestry, North Carolina State University, Raleigh, NC 27695-8008. \\ email: rrubilar@ncsfnc.cfr.ncsu.edu, email: lee_allen@ncsu.edu \\ ${ }^{3}$ Forestal Mininco, Casilla 43-C, Concepción, Chile. email: jalvarez@formin.cmpc.cl
}

\begin{abstract}
SUMMARY
Four radiata pine (Pinus radiata) stands were established on recent volcanic ash, volcanic sands, old volcanic ash and fluvial sedimentation in a granitic zone in Chile in 2000. Weed control (none or two year banded), fertilization (1.5 g B per tree or $150 \mathrm{~g}$ diammonium phosphate+1.5 g B per tree), soil tillage (shovel or subsoil), and all combinations of the individual treatments were applied with four replications at each site and analyzed as a split plot design with soil tillage as the main plots and weed control and fertilization as the sub plots. Treated plot area was at least 0.4 ha with $10 \mathrm{~m}$ buffers between all plots. Height, root collar diameter and diameter at breast height were measured three years after planting and foliar nutrient concentrations were measured two years after planting. All four sites exhibited positive growth responses to weed control with an average response to weed control across all sites of $3.1 \mathrm{~cm}$ in diameter and $1 \mathrm{~m}$ in height after three years. A positive height response $(10 \mathrm{~cm})$ to fertilization was observed on the volcanic sands. However, foliar nutrient analysis indicated that the added fertilizers may not have been available to the crop trees due to the timing of application. Subsoil tillage improved growth on the volcanic sand and the fluvial sedimentation sites, however the magnitude of response was $95 \%$ and $42 \%$ less than the response to weed control on these same sites, respectively. Weed control and subsoil tillage reduced variability in height at all sites. We hypothesized that early rotation growth gain from weed control would be maintained throughout the rotation (Type B) on old volcanic ash and the fluvial sedimentation sites while the growth gain on the recent volcanic ash and the volcanic sand sites would be partially or completely lost by the end of the rotation (Type C). Certainly, weed control is recommended for the site types represented in these trials. Fertilization along with weed control is recommended on the volcanic sands. Additional study managing the timing of fertilizer application is indicated as the applied fertilizers may not have been available to the crop trees. Subsoil tillage may not be needed on these site types however secondary benefits like improved traffic-ability and ease in planting resulting from subsoil tillage need to be quantified to better evaluate subsoil tillage benefits.
\end{abstract}

Key words: stand establishment, weed control, fertilization, soil tillage, Pinus radiata.

\section{RESUMEN}

Se iniciaron en el año 2000 ensayos para investigar la respuesta a la preparación de suelos (pala vs. subsolado), control de malezas (sin control vs. dos años en bandas) y fertilización (1,5 g de B por planta vs. $150 \mathrm{~g}$ de fosfato diamónico + 1,5 g de B por planta) al establecimiento de pino radiata (Pinus radiata D. Don) en Chile. Los ensayos se establecieron en sitios con suelos de cenizas volcánicas recientes, cenizas volcánicas antiguas ("rojo arcillosos volcánicos"), arenas volcánicas y sedimentos fluviales depositados sobre material granítico. El diseño experimental correspondió a parcelas divididas, donde áreas con preparación de suelos (parcelas principales) fueron divididas en parcelas con control de malezas y fertilización (subparcelas), considerando un área mínima de tratamiento de 0,4 
BOSQUE 25(2): 5-15, 2004

Radiata pine response to tillage, fertilization, and weed control in Chile

ha incluyendo buffers de $10 \mathrm{~m}$ entre parcelas. Mediciones de altura, diámetro de cuello y diámetro a la altura del pecho (DAP) fueron obtenidas durante tres años, junto con muestreos foliares durante los dos primeros años. Al tercer año de crecimiento, todos los sitios presentaron respuestas positivas al control de malezas con un promedio de 3,1 cm en diámetro y $1 \mathrm{~m}$ en altura. Respuestas positivas a la fertilización en altura $(0,1 \mathrm{~m})$ fueron obtenidas solo en sitios de arenas volcánicas; análisis foliares nutricionales revelaron una escasa absorción de los nutrientes en la plantación posiblemente dada una aplicación tardía de los fertilizantes. El subsolado mostró respuestas positivas en suelos de arenas volcánicas y de sedimentos fluviales, sin embargo, la respuesta fue $95 \%$ y $42 \%$ menor a la obtenida para control de malezas en estos sitios respectivamente. El control de malezas y el subsolado redujeron la variabilidad en altura en todos los sitios. Nuestra hipótesis es que la temprana respuesta al control de malezas se mantendrá hasta la edad de rotación (curva tipo B) para sitios de cenizas volcánicas antiguas y en sedimentos fluviales sobre material granítico; no obstante, en sitios de cenizas volcánicas recientes y arenas volcánicas esta respuesta decrecerá o desaparecerá (curva tipo C) a la edad de rotación. Indudablemente, en todos los sitios evaluados, el control de malezas es recomendable. La fertilización es recomendable junto con el control de malezas en sitios de arenas volcánicas. Por tanto, estudios adicionales son necesarios para determinar la época oportuna de fertilización que asegure una adecuada absorción de los nutrientes por parte de la plantación. El subsolado no es necesario en los sitios evaluados, sin embargo, efectos indirectos tales como: mejor accesibilidad, rendimiento y calidad de plantación, deben ser cuantificados al evaluar los beneficios de esta actividad.

Palabras clave: establecimiento de plantaciones, control de malezas, fertilización, subsolado, Pinus radiata.

\section{INTRODUCTION}

Quantifying long term growth responses to silvicultural treatments applied at the time of planting is essential for developing cost-effective and environmentally sustainable silvicultural systems for intensively managed plantations. The magnitude and duration of response to treatment are a function of how the imposed silvicultural treatments affect site resource availability and the ability of the crop plants to acquire those resources. Individual silvicultural treatments may affect more than one resource and may have short or long term effects (1). For example, vegetation control may increase the availability of light, water and nutrients for crop trees in the short-term where grass is controlled or over the long-term where woody brush is controlled.

The response of a forest stand to silvicultural treatments imposed at, or near, time of planting varies over time as both resource availability and the stand's demand for resources change. To assist in projecting early growth responses to silvicultural treatment to the end of a rotation, height growth response patterns have been grouped into three general types (A, B, and C) $(2,3)$. Growth responses to treatment are classified as Type $\mathrm{A}$ if gains in growth continue to increase through the rotation, Type B if growth gains are achieved early and then maintained, and Type $\mathrm{C}$ if early growth gains are either partially or completely lost by the end of the rota- tion. Identifying the appropriate response type (A, $\mathrm{B}, \mathrm{C}$ ) allows more accurate projection of the gains observed relative to non-treated areas. Also, identifying and minimizing the use of silvicultural treatments that are redundant (e.g. both weed control and fertilization may increase nutrient availability to crop plants) or unnecessary (e.g. soil cultivation in soils without root growth restrictions) will improve the profitability of the overall system.

Much research has been done in other areas of the world with early cultural treatments (4-9); however, a well designed and executed trial base is needed in Chile to provide long-term growth data for quantifying and modeling the impacts of early cultural treatment on plantation development and yield. Additionally these trials will provide a greater understanding of the soil and climatic factors that limit production and the effectiveness of various early cultural treatments in ameliorating these limitations.

Several studies examining early cultural treatment effects on the growth of radiata pine (Pinus radiata) in Chile provided excellent information on early responses to cultural treatment (10-12). However, these studies were not designed to be measured through the entire rotation as they have small plot sizes, small buffers and few trees with in each treated plot. Studies which avoided these limitations were needed to quantify the long-term effects of the most promising treatments identified in the existing studies. 
Our objective in this study was to quantify long term radiata pine responses to soil tillage, fertilization and vegetation control applied singly and in combination. Presented here are results through three years after planting.

\section{MATERIAL AND METHODS}

Four studies across a range of soil and climate conditions in Chile were installed in 2000 (table 1). The sites were on four different soil types: dry sands (La Reforma), fluvial sedimentation in a granitic zone (Monterrey), red clay (Laurel Poniente) and volcanic ash (Parcelas Coipue). One site was a pastureland conversion (Parcelas Coipue) while the others were cut over sites.

The planned experimental design was a split plot design with the soil tillage treatments (shovel, or subsoil) making up the main plots and a factorial application of the weed control (none, or two year banded) and fertilization (1.5 g B per tree, or $150 \mathrm{~g}$ diammonium phosphate $+1.5 \mathrm{~g} \mathrm{~B}$ per tree) as subplots with four replications at each site. However, soil tillage treatments were applied prior to plot establishment because of logistical issues related to the timing of tillage operations. The tillage main plots were randomly applied at each site and no bias was observed in plots established in the different tilled areas, consequently we completed the analysis as a split plot design. Soil tillage treatments were use of a shovel at the planting site to turn the soil or use of a bedding plow with a subsoil shank extending to a depth of $60 \mathrm{~cm}$ in the soil. Weed control used mechanical (hand weeding) and chemical (glyphosate) methods to maintain a $2 \mathrm{~m}$ weed free band centered on the planting row for the first two years after planting. The fertilization rates yielded elemental per hectare rates of 27,30 and $1.5 \mathrm{~kg} / \mathrm{ha}$ for nitrogen $(\mathrm{N})$, phosphorus (P) and boron (B), respectively for the three sites (Parcelas Coipue, Laurel Poniente, and Monterrey) with 1000 stems per hectare. For La Reforma, the only site with 1200 stems per hectare the elemental per hectare rates were 32, 36, and $1.8 \mathrm{~kg} / \mathrm{ha}$ for nitrogen $(\mathrm{N})$, phosphorus $(\mathrm{P})$ and boron (B), respectively. Plots were established with a measurement plot of at least 0.08 ha that included one hundred measurement trees. Each measurement plot was centered in a treated area of

TABLE 1

Site information for the four sites examined in this study.

Ubicación y características de los sitios estudiados.

\begin{tabular}{|c|c|c|c|c|}
\hline Site Name & Parcelas Coipue & La Reforma & Laurel Poniente & Monterrey \\
\hline $\begin{array}{l}\text { Latitude and } \\
\text { longitude }\end{array}$ & $\begin{array}{c}39^{\circ} 4^{\prime} 40^{\prime \prime} \mathrm{S} \\
72^{\circ} 24^{\prime} 23^{\prime \prime} \mathrm{W}\end{array}$ & $\begin{array}{c}37^{\circ} 10^{\prime} 40^{\prime \prime} \mathrm{S} \\
72^{\circ} 15^{\prime} 47^{\prime \prime} \mathrm{W}\end{array}$ & $\begin{array}{l}37^{\circ} 50^{\prime} 43^{\prime \prime} \mathrm{S} \\
72^{\circ} 20^{\prime} 5^{\prime \prime} \mathrm{W}\end{array}$ & $\begin{array}{c}37^{\circ} 19^{\prime} 23^{\prime \prime} \mathrm{S} \\
72^{\circ} 43^{\prime} 24^{\prime \prime} \mathrm{W}\end{array}$ \\
\hline $\begin{array}{l}\text { Mean annual temperature } \\
\text { (degrees C) }\end{array}$ & 10.7 & 13.7 & 13.3 & 10.9 \\
\hline $\begin{array}{l}\text { Mean annual } \\
\text { precipitation }(\mathrm{mm})\end{array}$ & 2180 & 1160 & 1100 & 1300 \\
\hline Geology & $\begin{array}{l}\text { Recent volcanic } \\
\text { ash }\end{array}$ & Volcanic sands & $\begin{array}{l}\text { Red clay-old } \\
\text { volcanic ash }\end{array}$ & $\begin{array}{l}\text { Fluvial sedimentation } \\
\text { in a granitic zone }\end{array}$ \\
\hline Soil taxonomic name & $\begin{array}{l}\text { Medial, Mesic Typic } \\
\text { Haploxerands }\end{array}$ & $\begin{array}{l}\text { Fragmental, Thermic } \\
\text { Dystric Xerorthents }\end{array}$ & $\begin{array}{l}\text { Very fine, Mixed, } \\
\text { Thermic Typic } \\
\text { Rhodoxeralfs }\end{array}$ & $\begin{array}{l}\text { Fine Loamy, Thermic } \\
\text { Dystric Xerochrepts }\end{array}$ \\
\hline Drainage & Well & $\begin{array}{l}\text { Somewhat } \\
\text { excessively well }\end{array}$ & Well & Well \\
\hline
\end{tabular}


BOSQUE 25(2): 5-15, 2004

Radiata pine response to tillage, fertilization, and weed control in Chile

0.4 ha with between treatment plot buffers of at least $10 \mathrm{~m}$.

Soil tillage treatments were applied in May 2000. Trees were planted and fertilized in July 2000. Weed control began in July 2000 and continued until July 2002.

Planted pines were measured immediately after planting and in the dormant season (June to August) one, two and three growing seasons after planting. Assessments of pine tree height, root collar diameter (RCD) (in the first three years), and diameter at $1.4 \mathrm{~m}$ height (DBH) (beginning in the third year when most trees achieved a DBH) were completed on all measurement trees.

Foliage was collected from five dominant or codominant pine trees in each plot during the dormant season after two growing seasons. Foliage was collected from the first flush foliage on a primary lateral branch in the upper one-third of the live crown. Foliage samples were dried to a constant weight at $70^{\circ} \mathrm{C}$, ground and analyzed for nutrients using $\mathrm{CHN}$ (for nitrogen) and a nitric acid digest and ICP analysis for all other elements.

For each study, a split plot analysis of variance (ANOVA) was used to test for soil tillage main effects using block $\mathrm{x}$ soil tillage as the error term. Vegetation control and fertilizer main effects and the weed control $\mathrm{x}$ fertilizer, soil tillage $\mathrm{x}$ weed control, soil tillage $\mathrm{x}$ fertilizer and soil tillage $\mathrm{x}$ weed control $\mathrm{x}$ fertilizer interaction effects were tested with the block $\mathrm{x}$ soil tillage $\mathrm{x}$ weed control $x$ fertilizer as the error term. The level of statistical significance used was $\mathrm{p}<0.05$.

\section{RESULTS}

Weed control increased pine growth at all four sites through the first three years after planting. Weed control resulted in statistically significant increases in RCD, DBH and height at all sites (table 2). These growth gains due to weed control whether applied alone or with the other treatments ranged from 43 to $155 \%$ in RCD, from 29 to $406 \%$ in $\mathrm{DBH}$ and 25 to $124 \%$ in height growth for the first three years across all sites (table 3 ). After three years, the growth gains attributable to weed control when applied alone for RCD, DBH and height averaged 2.6, 1.8 and 86 $\mathrm{cm}$, respectively, for all sites.

Fertilization with diammonium phosphate resulted in a statistically significant increase in growth at only one site, La Reforma (dry sandy soil). However, the growth gains three years after treatment, while statistically significant, were relatively modest with increases of $0.2 \mathrm{~cm}(5 \%), 0.1$ $\mathrm{cm}(10 \%)$, and $10 \mathrm{~cm}(5 \%)$ for RCD, DBH and height, respectively (tables 2 and 3). When combined with weed control, fertilization resulted in a statistically significant increase (a significant $\mathrm{W}^{*} \mathrm{~F}$ term) at two sites, Parcelas Coipue (height) and La Reforma (RCD and DBH). More fertilizer response was observed when weeds were controlled indicating a synergistic (more than additive) response for trees at these sites.

Soil tillage resulted in a statistically significant increase in growth at two sites, La Reforma (RCD and $\mathrm{DBH}$ ) and Monterrey (RCD, DBH, and height). After three years of growth at La Reforma, RCD and DBH were increased $0.1 \mathrm{~cm}(5 \%)$ and $0.1 \mathrm{~cm}$ (8\%), respectively. Response to soil tillage at Monterrey was more pronounced with gains of $1.0(36 \%), 1.3(130 \%)$, and $50(38 \%) \mathrm{cm}$ for RCD, $\mathrm{DBH}$, and height, respectively. The combination of weed control and soil tillage resulted in a significant interaction only at Parcelas Coipue where a more than additive effect was observed on RCD growth response. In this case, RCD three year responses to soil tillage alone, weed control alone and the combination of soil tillage and weed control were $-0.3,3.3$, and $4.2 \mathrm{~cm}$, respectively.

Survival at Parcelas Coipue and Laurel Poniente was very good for all treatments with three year survival rates of at least $94 \%$ (table 4). At La Reforma the control and fertilization alone treatments had three year survival rates of 75 and $68 \%$, respectively, while the remaining Survival at Parcelas Coipue and Laurel Poniente was very good for all treatments with three year survival rates of at least 94\% (table 4). At La Reforma the control and fertilization alone treatments had three year survival rates of 75 and $68 \%$, respectively, while the remaining treatments had survival at $92 \%$ or more. The Monterrey study exhibited lower survival across all treatments with the range in three year survival from 61 (in the soil tillage and fertilization treatment) to $89 \%$ (in the weed control and fertilizer treatment). When vegetation control was applied survival was at least $82 \%$. The majority of the mortality observed at Monterrey occurred in the first year after planting.

Foliar $\mathrm{N}$ and $\mathrm{P}$ concentrations did not indicate any gross nutrient limitations at the four sites (table 5). Average concentrations at Parcelas Coipue, La Reforma, Laurel Poniente, and Monterrey were 
TABLE 2

Summary of statistical significance (prob $>F$ ) of main effects and coefficient of variation for three year growth at the four sites.

Resumen de pruebas estadísticas (prob $>F$ ) para los efectos principales y coeficientes de variación de los parámetros de crecimiento a los tres años de edad en los sitios evaluados.

\begin{tabular}{|c|c|c|c|}
\hline Effects & $\begin{array}{l}\text { Root Collar } \\
\text { Diameter }\end{array}$ & Diameter & Height \\
\hline & \multicolumn{3}{|c|}{ Parcelas Coipue } \\
\hline Soil tillage (S) & 0.589 & 0.812 & 0.098 \\
\hline Fertilization (F) & 0.895 & 0.994 & 0.805 \\
\hline Weed control (W) & 0.001 & 0.001 & 0.001 \\
\hline $\mathrm{S}^{*} \mathrm{~F}$ & 0.526 & 0.711 & 0.630 \\
\hline $\mathrm{S} * \mathrm{~W}$ & 0.021 & 0.215 & 0.138 \\
\hline $\mathrm{F}^{*} \mathrm{~W}$ & 0.181 & 0.067 & $\mathbf{0 . 0 2 0}$ \\
\hline $\mathrm{S}^{*} \mathrm{~F}^{*} \mathrm{~W}$ & 0.299 & 0.221 & 0.207 \\
\hline \multirow[t]{2}{*}{ C.V. } & 6.0 & 3.2 & 2.7 \\
\hline & \multicolumn{3}{|c|}{ La Reforma } \\
\hline Soil tillage (S) & 0.044 & 0.043 & 0.076 \\
\hline Fertilization $(\mathrm{F})$ & 0.001 & 0.001 & 0.001 \\
\hline Weed control (W) & 0.001 & 0.001 & 0.001 \\
\hline $\mathrm{S} * \mathrm{~F}$ & 0.264 & 0.034 & 0.051 \\
\hline $\mathrm{S} * \mathrm{~W}$ & 0.933 & 0.182 & 0.127 \\
\hline $\mathrm{F}^{*} \mathrm{~W}$ & 0.025 & 0.007 & 0.183 \\
\hline $\mathrm{S} * \mathrm{~F} * \mathrm{~W}$ & 0.610 & 0.468 & 0.253 \\
\hline \multirow[t]{2}{*}{ C.V. } & 12.3 & 20.1 & 9.2 \\
\hline & \multicolumn{3}{|c|}{ Laurel Poniente } \\
\hline Soil tillage (S) & 0.918 & 0.829 & 0.461 \\
\hline Fertilization (F) & 0.273 & 0.176 & 0.936 \\
\hline Weed control (W) & 0.001 & 0.001 & 0.001 \\
\hline $\mathrm{S} * \mathrm{~F}$ & 0.803 & 0.725 & 0.564 \\
\hline $\mathrm{S} * \mathrm{~W}$ & 0.087 & 0.133 & 0.138 \\
\hline $\mathrm{F}^{*} \mathrm{~W}$ & 0.273 & 0.096 & 0.658 \\
\hline $\mathrm{S}^{*} \mathrm{~F}^{*} \mathrm{~W}$ & 0.369 & 0.635 & 0.486 \\
\hline \multirow[t]{2}{*}{ C.V. } & 11.0 & 13.5 & 10.3 \\
\hline & \multicolumn{3}{|c|}{ Monterrey } \\
\hline Soil tillage (S) & 0.002 & 0.003 & 0.001 \\
\hline Fertilization $(\mathrm{F})$ & 0.225 & 0.118 & 0.443 \\
\hline Weed control (W) & 0.001 & 0.001 & 0.001 \\
\hline $\mathrm{S} * \mathrm{~F}$ & 0.942 & 0.735 & 0.967 \\
\hline $\mathrm{S} * \mathrm{~W}$ & 0.434 & 0.719 & 0.606 \\
\hline $\mathrm{F}^{*} \mathrm{~W}$ & 0.668 & 0.515 & 0.687 \\
\hline $\mathrm{S}^{*} \mathrm{~F}^{*} \mathrm{~W}$ & 0.968 & 0.724 & 0.669 \\
\hline C.V. & 13.5 & 22.1 & 16.5 \\
\hline
\end{tabular}


BOSQUE 25(2): 5-15, 2004

Radiata pine response to tillage, fertilization, and weed control in Chile

TABLE 3

Three-year growth and treatment $(\mathrm{W}=$ weed control, $\mathrm{F}=$ fertilization, $\mathrm{S}=$ soil tillage $)$ responses for all sites.

Respuestas al tercer año a los tratamientos aplicados en cada sitio $(\mathrm{W}=\mathrm{C}$. de malezas, $\mathrm{F}=$ fertilización, $\mathrm{S}=$ Prep. de suelo).

\begin{tabular}{|c|c|c|c|c|c|c|c|c|c|}
\hline \multirow[b]{2}{*}{ Treatment } & \multicolumn{3}{|c|}{ Root Collar Diameter } & \multicolumn{3}{|c|}{ Diameter } & \multicolumn{3}{|c|}{ Height } \\
\hline & $\begin{array}{c}\text { Growth } \\
(\mathrm{cm})\end{array}$ & $\begin{array}{l}\text { Response } \\
\quad(\mathrm{cm})\end{array}$ & $\begin{array}{c}\text { Response } \\
\%\end{array}$ & $\begin{array}{c}\text { Growth } \\
(\mathrm{cm})\end{array}$ & $\begin{array}{l}\text { Response } \\
\quad(\mathrm{cm})\end{array}$ & $\begin{array}{c}\text { Response } \\
\%\end{array}$ & $\begin{array}{l}\text { Growth } \\
\text { (m) }\end{array}$ & $\begin{array}{l}\text { Response } \\
\text { (m) }\end{array}$ & $\begin{array}{c}\text { Response } \\
\%\end{array}$ \\
\hline \multicolumn{10}{|c|}{ Parcelas Coipue } \\
\hline Control & 7.6 & & & 5.4 & & & 3.2 & & \\
\hline $\mathrm{W}$ & 10.9 & 3.3 & 43 & 7.1 & 1.6 & 29 & 4.0 & 0.8 & 26 \\
\hline $\mathrm{F}$ & 7.3 & -0.3 & -5 & 5.0 & -0.5 & -8 & 3.0 & -0.2 & -7 \\
\hline $\mathrm{W}+\mathrm{F}$ & 11.4 & 3.8 & 50 & 7.6 & 2.2 & 40 & 4.3 & 1.1 & 33 \\
\hline $\mathrm{S}$ & 7.3 & -0.3 & -4 & 5.0 & -0.4 & -8 & 2.8 & -0.4 & -11 \\
\hline $\mathrm{S}+\mathrm{W}$ & 11.8 & 4.2 & 55 & 7.4 & 2.0 & 37 & 4.0 & 0.8 & 25 \\
\hline $\mathrm{S}+\mathrm{F}$ & 7.1 & -0.5 & -7 & 4.8 & -0.6 & -11 & 2.7 & -0.5 & -15 \\
\hline $\mathrm{S}+\mathrm{F}+\mathrm{W}$ & 12.0 & 4.4 & 58 & 7.5 & 2.1 & 38 & 4.1 & 0.9 & 28 \\
\hline \multicolumn{10}{|c|}{ La Reforma } \\
\hline Control & 3.0 & & & 0.9 & & & 1.3 & & \\
\hline $\mathrm{W}$ & 5.0 & 1.9 & 64 & 2.3 & 1.4 & 146 & 2.0 & 0.7 & 51 \\
\hline $\mathrm{F}$ & 3.2 & 0.2 & 5 & 1.0 & 0.1 & 10 & 1.4 & 0.1 & 5 \\
\hline $\mathrm{W}+\mathrm{F}$ & 5.5 & 2.5 & 82 & 2.7 & 1.7 & 186 & 2.0 & 0.7 & 57 \\
\hline $\mathrm{S}$ & 3.2 & 0.1 & 5 & 1.0 & 0.1 & 8 & 1.3 & 0.0 & 1 \\
\hline $\mathrm{S}+\mathrm{W}$ & 5.0 & 2.0 & 66 & 2.5 & 1.5 & 162 & 2.0 & 0.7 & 54 \\
\hline $\mathrm{S}+\mathrm{F}$ & 3.4 & 0.4 & 14 & 1.3 & 0.3 & 37 & 1.4 & 0.1 & 10 \\
\hline $\mathrm{S}+\mathrm{F}+\mathrm{W}$ & 5.9 & 2.9 & 95 & 3.2 & 2.2 & 239 & 2.2 & 0.9 & 72 \\
\hline \multicolumn{10}{|c|}{ Laurel Poniente } \\
\hline Control & 3.9 & & & 2.0 & & & 1.7 & & \\
\hline $\mathrm{W}$ & 6.7 & 2.8 & 72 & 4.0 & 1.9 & 93 & 2.6 & 0.9 & 54 \\
\hline $\mathrm{F}$ & 4.0 & 0.1 & 2 & 2.0 & 0.0 & -1 & 1.7 & 0.0 & -1 \\
\hline $\mathrm{W}+\mathrm{F}$ & 6.8 & 2.9 & 76 & 4.3 & 2.2 & 108 & 2.5 & 0.9 & 51 \\
\hline $\mathrm{S}$ & 4.3 & 0.4 & 9 & 2.3 & 0.3 & 13 & 1.8 & 0.2 & 10 \\
\hline $\mathrm{S}+\mathrm{W}$ & 6.3 & 2.4 & 61 & 3.7 & 1.6 & 80 & 2.5 & 0.8 & 48 \\
\hline $\mathrm{S}+\mathrm{F}$ & 4.2 & 0.3 & 7 & 2.3 & 0.2 & 10 & 1.8 & 0.1 & 8 \\
\hline $\mathrm{S}+\mathrm{F}+\mathrm{W}$ & 6.6 & 2.7 & 69 & 4.1 & 2.0 & 100 & 2.5 & 0.9 & 52 \\
\hline \multicolumn{10}{|c|}{ Monterrey } \\
\hline Control & 2.8 & & & 1.0 & & & 1.4 & & \\
\hline W & 5.4 & 2.6 & 95 & 3.4 & 2.3 & 225 & 2.5 & 1.1 & 75 \\
\hline $\mathrm{F}$ & 2.9 & 0.2 & 6 & 1.4 & 0.4 & 39 & 1.5 & 0.1 & 7 \\
\hline $\mathrm{W}+\mathrm{F}$ & 5.8 & 3.0 & 109 & 3.9 & 2.9 & 279 & 2.6 & 1.1 & 82 \\
\hline$S$ & 3.8 & 1.0 & 36 & 2.4 & 1.3 & 130 & 1.9 & 0.5 & 38 \\
\hline $\mathrm{S}+\mathrm{W}$ & 6.8 & 4.0 & 145 & 4.7 & 3.7 & 355 & 3.0 & 1.6 & 115 \\
\hline $\mathrm{S}+\mathrm{F}$ & 4.0 & 1.2 & 44 & 2.4 & 1.4 & 136 & 1.9 & 0.5 & 37 \\
\hline $\mathrm{S}+\mathrm{F}+\mathrm{W}$ & 7.1 & 4.3 & 156 & 5.3 & 4.2 & 406 & 3.2 & 1.7 & 124 \\
\hline
\end{tabular}

10 
TABLE 4

Three year survival for all studies.

Sobrevivencia al tercer año para los tratamientos aplicados en cada sitio.

\begin{tabular}{|lrrrr|}
\hline \multirow{2}{*}{ Treatment } & \multicolumn{4}{c|}{ Study } \\
\cline { 2 - 5 } & Parcelas Coipue & La Reforma & Laurel Poniente & Monterrey \\
\hline Control & 94 & 75 & 99 & 75 \\
Weed Control (W) & 97 & 99 & 99 & 85 \\
Fertilization (F) & 96 & 68 & 98 & 76 \\
W+F & 99 & 98 & 100 & 89 \\
Soil tillage (S) & 97 & 93 & 99 & 66 \\
S+W & 100 & 99 & 100 & 83 \\
S+F & 97 & 92 & 100 & 61 \\
S+F+W & 100 & 100 & 100 & 82 \\
\hline
\end{tabular}

$1.95,1.44,1.78$ and $1.50 \%$ for $\mathrm{N}$ and $0.172,0.180$, 0.184 , and $0.183 \%$ for $\mathrm{P}$, respectively (table 5). Weed control had strong negative effects on foliar nutrient concentrations at Parcelas Coipue where weed control significantly reduced $\mathrm{N}, \mathrm{P}, \mathrm{Ca}, \mathrm{Mg}, \mathrm{S}$, $\mathrm{B}, \mathrm{Zn}$, and $\mathrm{Mn}$ concentrations in the foliage (tables 5 and 6). Interestingly, fertilization did not have a significant positive effect on foliar $\mathrm{N}$ or $\mathrm{P}$ concentrations at any site.

Foliar boron (B) concentrations were low at Laurel Poniente and Monterrey where the averages across all treatments were 10.2 and $9.5 \mathrm{ppm}$, respectively (table 5). These values are below that which would be considered limiting for growth in radiata pine (12 ppm) (15). The other sites had foliar B concentrations that would not be considered limiting with values of 14.9 and $28.2 \mathrm{ppm}$ for Parcelas Coipue and La Reforma, respectively. Three of the sites (Parcelas Coipue, La Reforma, and Laurel Poniente) had a significant reduction in foliar B concentration and all four sites exhibited a significant increase in leaf weight as a result of weed control, as might be expected with the observed greater foliage and tree growth.

\section{DISCUSSION AND CONCLUSIONS}

Clearly weed control is the most important of the three factors tested for improving early growth across all sites. Other studies have also found that early weed control is important in improving the early growth of the crop species $(4,7)$. The growth improvements with weed control might be expected to follow a Type B (early growth gains maintained throughout rotation) or Type $\mathrm{C}$ (early growth gains partially or completely lost by end of rotation) response depending on which resources available to the pines have been affected by the weed control. A Type B response is the result of an early short-term increase in availability of resources that would have been permanently lost to crop trees if the resources had not been utilized at that time (e.g., water or light). A Type $\mathrm{C}$ response is the result of an early short-term increase in availability of existing site resources (e.g., nutrients) or the allocation of these existing site resources to crop trees early in the rotation. For Parcelas Coipue and La Reforma, the observed response may be a Type $\mathrm{C}$ since these sites also responded to fertilizer or the combination of fertilizer and weed control and consequently the resource affected by weed control may have been improved nutrient availability. However, at Laurel Poniente and Monterrey the response may be a Type $\mathrm{B}$ response because these sites did not respond to additional nutrients and the resources affected by weed control were most likely water and light.

The fertilizer materials as applied may not have been available to the trees at all sites. The low foliar B concentrations at two sites and the general lack of increase in foliar $\mathrm{N}$ and $\mathrm{P}$ concentra- 
BOSQUE 25(2): 5-15, 2004

Radiata pine response to tillage, fertilization, and weed control in Chile

TABLE 5

Foliar nitrogen $(\mathrm{N})$, phosphorus $(\mathrm{P})$ and boron $(\mathrm{B})$ concentrations and percent response to treatment (W = weed control, $\mathrm{F}=$ fertilization, $\mathrm{S}=$ soil tillage) two years after treatment.

Concentraciones foliares de nitrógeno $(\mathrm{N})$, fósforo $(\mathrm{P})$ y boro $(\mathrm{B})$ y respuesta porcentual a los dos años post-aplicación de cada tratamiento $(\mathrm{W}=\mathrm{C}$. de malezas, $\mathrm{F}$ = fertilización, $\mathrm{S}=$ Prep. de suelo).

\begin{tabular}{|c|c|c|c|c|c|c|}
\hline \multirow{3}{*}{ Treatment } & \multicolumn{2}{|c|}{$\mathrm{N}$} & \multicolumn{2}{|c|}{$\mathrm{P}$} & \multicolumn{2}{|c|}{ B } \\
\hline & $\%$ & $\%$ Response & $\%$ & $\%$ Response & ppm & \% Response \\
\hline & \multicolumn{6}{|c|}{ Parcelas Coipue } \\
\hline Control & 1.94 & & 0.193 & & 17.3 & \\
\hline W & 1.86 & -4 & 0.156 & -19 & 13.8 & -20 \\
\hline $\mathrm{F}$ & 1.94 & 0 & 0.192 & -1 & 15.5 & -10 \\
\hline $\mathrm{W}+\mathrm{F}$ & 1.81 & -7 & 0.141 & -27 & 13.3 & -23 \\
\hline $\mathrm{S}$ & 2.10 & 8 & 0.200 & 3 & 14.1 & -18 \\
\hline $\mathrm{S}+\mathrm{W}$ & 1.98 & 2 & 0.174 & -10 & 14.2 & -18 \\
\hline $\mathrm{S}+\mathrm{F}$ & 2.10 & 8 & 0.176 & -9 & 16.6 & -4 \\
\hline \multirow[t]{2}{*}{$\mathrm{S}+\mathrm{F}+\mathrm{W}$} & 1.92 & -1 & 0.167 & -13 & 15.2 & -12 \\
\hline & \multicolumn{6}{|c|}{ La Reforma } \\
\hline Control & 1.43 & & 0.179 & & 27.7 & \\
\hline W & 1.53 & 7 & 0.187 & 4 & 27.6 & 0 \\
\hline $\mathrm{F}$ & 1.38 & -4 & 0.163 & -9 & 31.5 & 14 \\
\hline $\mathrm{W}+\mathrm{F}$ & 1.46 & 2 & 0.194 & 8 & 25.1 & -9 \\
\hline S & 1.39 & -3 & 0.162 & -10 & 29.9 & 8 \\
\hline $\mathrm{S}+\mathrm{W}$ & 1.45 & 1 & 0.195 & 8 & 25.9 & -6 \\
\hline $\mathrm{S}+\mathrm{F}$ & 1.46 & 2 & 0.167 & -7 & 31.7 & 15 \\
\hline \multirow[t]{2}{*}{$\mathrm{S}+\mathrm{F}+\mathrm{W}$} & 1.40 & -2 & 0.182 & 1 & 27.8 & 1 \\
\hline & \multicolumn{6}{|c|}{ Laurel Poniente } \\
\hline Control & 1.79 & & 0.174 & & 12.3 & \\
\hline W & 1.77 & -1 & 0.165 & -5 & 8.5 & -31 \\
\hline $\mathrm{F}$ & 1.84 & 3 & 0.186 & 7 & 11.8 & -4 \\
\hline $\mathrm{W}+\mathrm{F}$ & 1.73 & -3 & 0.162 & -7 & 8.4 & -32 \\
\hline S & 1.66 & -7 & 0.198 & 14 & 11.4 & -7 \\
\hline $\mathrm{S}+\mathrm{W}$ & 1.74 & -3 & 0.175 & 1 & 10.1 & -18 \\
\hline $\mathrm{S}+\mathrm{F}$ & 1.84 & 3 & 0.193 & 11 & 10.7 & -12 \\
\hline \multirow[t]{2}{*}{$\mathrm{S}+\mathrm{F}+\mathrm{W}$} & 1.89 & 6 & 0.209 & 20 & 9.3 & -24 \\
\hline & \multicolumn{6}{|c|}{ Monterrey } \\
\hline Control & 1.27 & & 0.174 & & 10.4 & \\
\hline W & 1.41 & 11 & 0.165 & -5 & 8.6 & -17 \\
\hline $\mathrm{F}$ & 1.39 & 10 & 0.159 & -9 & 9.6 & -8 \\
\hline $\mathrm{W}+\mathrm{F}$ & 1.54 & 22 & 0.161 & -7 & 7.7 & -26 \\
\hline S & 1.82 & 43 & 0.209 & 20 & 9.7 & -6 \\
\hline $\mathrm{S}+\mathrm{W}$ & 1.60 & 26 & 0.193 & 11 & 9.2 & -12 \\
\hline $\mathrm{S}+\mathrm{F}$ & 1.60 & 26 & 0.217 & 25 & 9.8 & -5 \\
\hline $\mathrm{S}+\mathrm{F}+\mathrm{W}$ & 1.48 & 17 & 0.183 & 6 & 8.8 & -15 \\
\hline
\end{tabular}


BOSQUE 25(2): 5-15, 2004

Radiata pine response to tillage, fertilization, and weed control in Chile

TABLE 6

Number of studies with positive, none or negative responses on foliar element concentrations by silvicultural treatment.

Número de estudios con respuestas positivas, nulas o negativas en la concentración nutricional de elementos foliares para cada tratamiento silvícola.

\begin{tabular}{|c|c|c|c|c|c|c|c|c|c|c|c|}
\hline \multirow{2}{*}{$\begin{array}{l}\text { Response } \\
\text { direction }\end{array}$} & \multicolumn{10}{|c|}{ Element } & \multirow{2}{*}{$\begin{array}{c}\text { Leaf } \\
\text { Weight }\end{array}$} \\
\hline & $\mathrm{N}$ & $\mathrm{P}$ & $\mathrm{K}$ & $\mathrm{Ca}$ & $\mathrm{Mg}$ & $\mathrm{S}$ & B & $\mathrm{Cu}$ & $\mathrm{Zn}$ & Mn & \\
\hline \multicolumn{12}{|c|}{ Soil tillage } \\
\hline Positive & - & 1 & 1 & 1 & - & 1 & - & 1 & - & 1 & 1 \\
\hline None & 4 & 3 & 3 & 3 & 4 & 3 & 4 & 2 & 4 & 3 & 3 \\
\hline Negative & - & - & - & - & - & - & - & 1 & - & - & - \\
\hline \multicolumn{12}{|c|}{ Weed Control } \\
\hline Positive & - & 1 & 1 & - & - & - & - & 1 & - & - & 4 \\
\hline None & 3 & 2 & 3 & 3 & 2 & 3 & 1 & 3 & 2 & 1 & - \\
\hline Negative & 1 & 1 & - & 1 & 2 & 1 & 3 & - & 2 & 3 & - \\
\hline \multicolumn{12}{|c|}{ Fertilization } \\
\hline Positive & - & - & - & - & - & - & - & - & - & - & - \\
\hline None & 4 & 3 & 3 & 4 & 4 & 3 & 4 & 4 & 2 & 4 & 4 \\
\hline Negative & - & 1 & 1 & - & - & 1 & - & - & 2 & - & - \\
\hline
\end{tabular}

tions at all sites may indicate a problem with the timing of the application of the fertilizer materials.

Boron is moved with the transpiration stream and the growing seasons in Chile are generally dry. If the fertilizers were applied at a time after which there was little rainfall then the trees may not have been able to effectively capture the added nutrients. These results indicate that fertilization may be important at some sites but only when coupled with weed control. Additionally, fertilization may become important later in the life of the stand as the trees begin to better occupy the site and intra-specific competition increases. Fortunately, a treatment was added at study initiation that allows for subsequent fertilization so we may test this hypothesis.

Subsoil tillage provided little short term growth benefit to the trees at any site. This is in agreement with results from previous studies (13) where upland sites generally do not respond to sub-soiling as root development can readily occur in the well structured soil and also through old root channels. This is good news since soil tillage is often the most expensive site preparation technique when compared to weed control and fertilization. Significant savings will result by avoiding sub-soiling on similar sites. Soil tillage reduces root growth restrictions in high strength soils (well drained clays) and improves soil aeration in poorly drained soils and these responses will generally be observed early in the rotation. Consequently it is unlikely that subsoil tillage will provide growth benefits at a later time during the rotation. Soil tillage may also help to reduce the woody component of competing vegetation although this type of vegetation was not common on these sites. Additionally, Nilsson and Allen (14) found that intensive site preparation which included soil tillage may result in more uniform stands later in the life of the stand. The coefficient of variation for plot height in our study was improved at all sites by both subsoil tillage and weed control (table 7) and 
BOSQUE 25(2): 5-15, 2004

Radiata pine response to tillage, fertilization, and weed control in Chile

TABLE 7

Average plot coefficient of variation for height three years after planting.

Coeficiente de variación promedio en altura a los tres años para cada tratamiento y sitio.

\begin{tabular}{|c|c|c|c|c|c|c|}
\hline \multirow{2}{*}{ Year } & \multicolumn{2}{|c|}{ Tillage } & \multicolumn{2}{|c|}{ Weed control } & \multicolumn{2}{|c|}{ Fertilization } \\
\hline & Shovel & Subsoil Tillage & No WC & WC & B only & $\mathrm{B}+\mathrm{N}+\mathrm{P}$ \\
\hline \multicolumn{7}{|c|}{ Parcelas Coipue } \\
\hline 0 & 16.5 & 14.9 & 16.2 & 15.1 & 15.2 & 15.9 \\
\hline 1 & 17.7 & 16.2 & 20.5 & 14.0 & 16.0 & 17.6 \\
\hline 2 & 15.9 & 14.6 & 17.2 & 13.5 & 14.8 & 15.5 \\
\hline 3 & 16.0 & 15.6 & 18.0 & 14.0 & 15.7 & 15.9 \\
\hline \multicolumn{7}{|c|}{ La Reforma } \\
\hline 0 & 15.8 & 15.6 & 15.7 & 15.7 & 16.0 & 15.4 \\
\hline 1 & 23.9 & 19.4 & 26.2 & 17.6 & 20.5 & 22.1 \\
\hline 2 & 22.9 & 19.5 & 25.6 & 17.4 & 21.4 & 20.7 \\
\hline 3 & 22.5 & 19.4 & 25.0 & 17.4 & 21.8 & 20.0 \\
\hline \multicolumn{7}{|c|}{ Laurel Poniente } \\
\hline 0 & 14.6 & 15.6 & 14.8 & 15.4 & 14.8 & 15.4 \\
\hline 1 & 17.7 & 15.1 & 18.2 & 14.6 & 16.0 & 16.4 \\
\hline 2 & 18.9 & 16.2 & 19.5 & 15.8 & 16.2 & 18.4 \\
\hline 3 & 20.0 & 18.1 & 19.9 & 18.1 & 17.3 & 20.2 \\
\hline \multicolumn{7}{|c|}{ Monterrey } \\
\hline 0 & 16.7 & 16.6 & 16.1 & 17.0 & 16.4 & 16.8 \\
\hline 1 & 26.8 & 24.7 & 30.1 & 22.1 & 25.5 & 25.7 \\
\hline 2 & 27.5 & 25.0 & 30.5 & 22.6 & 26.8 & 25.6 \\
\hline 3 & 26.3 & 23.1 & 28.6 & 21.2 & 26.3 & 23.1 \\
\hline
\end{tabular}

Year 0 is at time of planting.

Año 0 es año de establecimiento.

hence use of weed control to reduce stand variability is a viable option.

The combination of subsoil tillage and weed control resulted in a positive synergistic response at Parcelas Coipue. This result is interesting in that subsoil tillage alone may yield a reduction in competing vegetation; however, this site was being converted from a farm field to plantation. Soil tillage may reduce barriers to rooting found in the soil as a result of farming practices. It appears that eliminating these barriers only affects pine growth in the presence of weed control. This response on sites being converted from farm land to plantations would likely be evident on all soil types.

The cause of relatively low survival at one site is not evident from these data. However, weed control appeared to mitigate the loss of trees. Issues related to the timing of planting and subsequent environmental conditions at Monterrey in the first year after planting need to be examined to 
identify the factors associated with the poor survival.

Weed control improved growth and increased stand homogeneity at all sites. Fertilization provided a positive response at the dry sandy site and positive synergistic responses were found when fertilization and weed control were combined on the sandy site and the recent volcanic ash. Subsoil tillage improved growth at the dry sandy site and the fluvial sedimentation site and improved stand homogeneity at all sites. Subsoil tillage and weed control resulted in synergistic positive responses on sites being converted from farm land to plantations.

Clearly weed control is essential to early stand growth on these site types and when allocating limited financial resources for stand establishment weed control is recommended. Fertilization will be important on nutrient poor sandy sites but should be applied in combination with weed control. While there are some early growth benefits from subsoil tillage, the response to weed control is much greater on sites that were responsive to both weed control and subsoil tillage and there was no additional response to the combination of subsoil tillage and weed control on the sites where both yielded significant responses as individual treatments. In most cases, the combined treatments resulted in additive effects. Consequently, the largest growth responses would be found in some combined treatment, however, from an economic perspective weed control alone may well be the best treatment on sites similar to the ones in this study.

\section{REFERENCES}

(1) ALLEN, H.L. Silvicultural Treatments to Enhance Productivity. Chap. 6, In: J. EVANS (ed). The Forests Handbook. Volume II. Blackwell Science Ltd., Oxford, UK. 2001. 382 p.

(2) HUGHES, J.H., R.G. CAMPBELL, H.W. DUZAN SR., C.S. DUDLEY. Site index adjustments for intensive forest management at North Carolina. Forest Research Technical Report. Weyerhaeuser Co., New Bern, NC. 1979. 12 p.

(3) MORRIS, L.A., R.F. LOWERY. Influences of site preparations on soil conditions affecting stand establishment and tree growth. South. J. Appl. For. 1988. vol.12, p. $170-178$.

(4) ALLEN, H.L., S. LEIN. Effects of site preparation, early fertilization, and weed control on 14-year old loblolly pine. Proc. South. Weed. Sci. Soc. 1998. vol. 51, p. 104-110.

(5) BOOMSMA, D.B., I.R. HUNTER. Effects of water, nutrients, and their interactions on tree growth, and plantation forest management practices in Australiasia: a review. For. Ecol. Manage. 1990. vol. 30, p. 455-476.

(6) FLINN, D.W., I. MOLLER, P. HOPMANS. Sustained growth responses to superphosphate applied to established stands of Pinus radiata. N.Z. J. For. Sci. 1979. vol. 9, p. 201-211.

(7) MASON, E.G., P.G. MILNE. Effects of weed control, fertilization, and soil cultivation on growth of Pinus radiata at midrotation in Canterbury, New Zealand. Can J. For. Res. 1999. vol. 29, p. 985-992.

(8) NAMBIAR, E.K.S., P.G. ZED. Influence of weeds on the water potential, nutrient content and growth of young radiata pine. Australian Forest Research. 1980. vol. 10, p. 279-288.

(9) SNOWDON, P., H.D. WARING. Long term nature of growth responses obtained to fertilizer and weed control applied at planting and their consequences for forest management. Pgs. 701-711. In: Proceedings IUFRO Symposium on Site and Productivity of Fast Growing Plantations. 1984. Vol. 2. South African Forest Research Inst. Pretoria, South Africa.

(10) ALVAREZ, J., J. RODRIGUEZ, D. SUAREZ. Mejoramiento de la productividad de plantaciones de Pinus radiata $\mathrm{D}$. Don, a través de un método racional de fertilización. Bosque. 1999. vol. 20, No 1, p. 23-36.

(11) KOGAN, M., R. FIGUEROA. Interferencia producida por las malezas durante los dos primeros años Pinus radiata D. Don. Bosque. 1999. vol. 20, No 1, p. 57-64.

(12) KOGAN, M., R. FIGUEROA, H. GILABERT. Weed control intensity effects on young radiata pine growth. Crop Protection 2002. vol. 21, p. 253-257.

(13) NCSFNC. Loblolly Pine Growth Response to Surface and Subsurface Tillage - Regionwide 16 Third Report NCSFNC Report N ${ }^{\circ} 48$. Dept. of Forestry. North Carolina State Univ., Raleigh, NC. 2002. 43 p.

(14) NILSSON, U, H.L. ALLEN. Short- and long- term effects of site preparation, fertilization, and vegetation control on growth and stand development of planted loblolly pine. For. Ecol. Manage. 2003. vol. 175, p. 367-377.

(15) WILL, G. Nutient deficiencies and fertilizer use in New Zealand exotic forests. Forest Research Institute Bulletin No. 97. FRI, New Zealand Forest Service, Rotorua, New Zealand. 1985. 53 p. 